BRIEF COMMUNICATION

\title{
FREQUENCY AND PRECOCITY OF HUMAN INTESTINAL PARASITISM IN A GROUP OF INFANTS FROM RIO DE JANEIRO, BRAZIL
}

\author{
Lêda Maria da COSTA-MACEDO(1) \& Luis REY(2)
}

KEYWORDS: Intestinal parasites; Epidemiological survey; Ascaris lumbricoides; Infant

Few cases of parasitic infection in infants by geo-helminths or other parasites transmitted by the fecal-oral route, mainly occurring during first months of life, have been reported in the literature $5.6,8$. The limited motor activity and the continuous protection against environmental exposure imposed by the persons responsible for children has led people to underestimate the magnitude of child contamination. In the present investigation we studied the frequency and precocity of enteroparasitosis in infants younger than one year from a low income group in Rio de Janeiro city. The study was carried out in a city area from March 1990 to May 1991. We analyzed 402 fecal samples using the MIFC method'. During this period, a total of 182 samples were taken from outpatients attended by the Public Health Service (Policlínica Américo Piquet Carneiro, Ministério da Saúde). The infants were followed up monthly in order to verify their development. The remaining samples (220) were directly obtained from children living in slums during visits by health workers. The selected slums were Formiga in Tijuca, Nelson Mandela in Manguinhos, Jacarezinho in Jacarezinho, and Vila Nova Cruzado in Jacarepaguá. The age of the infants (months) was recorded in all cases. Data were analyzed statistically by the chi-square test $\left(\mathrm{X}^{2}\right)$, with the level of significance set at $95 \%$.

We detected an $11.0 \%(44 / 402)$ rate of intestinal parasitic infection in our study. The most frequent parasites were Ascaris lumbricoides and Giardia lamblia, with $5.7 \%$ and $4.2 \%$ positive results, respectively. When the cases were divided according to locality, no significant difference were observed between the Public Health Service infants and those from the slums (Table 1). Monoparasitism was observed in $90.9 \%$ of the cases studied. Among the infants from the slums, younger than one year-old, 69.4\% were from Vila Nova Cruzado, $49.4 \%$ from Formiga, $33.7 \%$ from Mandela and $11.7 \%$ from Jacarezinho. A significant difference in the frequency of parasitism was observed between children under $(2.8 \%)$ and over (15.6\%) six months of age. Four children less than six months old who presented parasitism were infected with A. lumbricoides. The youngest patient was a two month-old infant with ascariosis from the Nelson Mandela community that was being partially breast-fed.

With respect to mortality among infants younger than one year in the Rio de Janeiro municipal district, $50 \%$ of all deaths are basically caused by diarrhea and/or malnutrition, which can be worsened by enteroparasitosis ${ }^{2}$. This highlights the importance of the $11 \%$ prevalence detected in the present study. The frequency of $A$. lumbricoides and G. lamblia in infants under one year of age detected in our study, has been previously reported in Brazil ${ }^{7}$. The prevalence of monoparasitism obtained was expected for this age group although the frequency of parasites differed from one community to another. $A$. lumbricoides was the most frequent and precocious parasite infecting infants under six months. In this study, the detection of this parasite in a two month-old infant was puzzling. Since $A$. lumbricoides is a geo-helminth parasite with a 60 day minimum pre-patent period, and has been reported to be responsible for congenital transmission in neonates ${ }^{3,4}$, we did our best to

TABLE 1

Distribution of 402 infants by locality and frequency of infection by enteroparasites

\begin{tabular}{cl}
\hline Localities & \% positivity* \\
\hline Public Service & $8.2(15 / 182)$ \\
Morro da Formiga & $16.5(15 / 91)$ \\
Nelson Mandela & $15.6(5 / 32)$ \\
Jacarezinho & $9.3(5 / 54)$ \\
Vila Nova Cruzado & $9.3(4 / 43)$ \\
\hline Total & $11.0(44 / 402)$ \\
\hline
\end{tabular}

* No significant difference.

(1)Departamento de Parasitologia da Universidade do Estado do Rio de Janeiro, Rua Teodoro da Silva 48, $5^{\circ}$ andar, $20511-001$ Rio de Janeiro, RJ, Brasil. (2)Departamento de Medicina Tropical do Instituto Oswaldo Cruz, FIOCRUZ, Caixa Postal 926, 21045-900 Rio de Janeiro, RJ, Brasil.

Correspondence to: L.M. da COSTA-MACEDO, Depto. Parasitologia, UERJ, Rua Teodoro da Silva 48, $5^{\circ}$ andar, 20511-001, Rio de Janeiro, RJ, Brasil 
COSTA-MACEDO, L.M. da \& REY, L. - Frequency and precocity of human intestinal parasitism in a group of infants from Rio de Janeiro, Brazil. Rev. Inst. Med. trop. S. Paulo, 39(5): 305-306, 1997.

investigate this possibility. However, the mother's parasitological exam carried out concurrently with the infant's proved negative. Unfortunately, fecal parasitology exams during the pre-natal period were not available. This infant has been partially breast-fed by his mother although we know that during this period a child should be exclusively breast-fed. Thus, considering the frequency of $11 \%$ detected and the extreme precocity of acquisition of a parasitic intestinal infection by infants, further studies are needed.

\section{REFERENCES}

1. BLAGG, W.; SCHLOEGEL, E. L.; MANSUR, N. S. G. et al. - A new concentration technic for the demonstration of protozoa and helminth eggs in feces. Amer. J. trop. Med. Hyg., 4: 23-28, 1955.

2. CARVALHO, M. L.; NIOBEY, F. M. L.; MIRANDA, N. N. et al. - Concordância na determinação da causa básica de óbito em menores de um ano na região metropolitana do Rio de Janeiro, 1986. Rev. Saúde públ. (S. Paulo), 24: 20-27, 1990.

3. CHU, W. G.; CHEN, P. M.; HUANG, C.C. et al. - Neonatal ascariasis. J. Pediat., 81: $783-785,1972$.
4. COSTA-MACEDO, L. M. \& REY, L. - Ascaris lumbricoides in neonate: evidence of congenital transmission of intestinal nematodes. Rev. Inst. Med. trop. S. Paulo, 32: 351-354, 1990.

5. GRANOT, E.; DECKELBAUM, R. J.; HELDENBERG, D. et al. Strongyloidiasis in infancy: case report and review. Israel J. med. Sci, 19: 1089-1093, 1983.

6. MANDARINO, E. - Um caso de parasitose intestinal em lactente. Rev. bras. Med., 18: 566, 1961.

7. MONTEIRO, C. A.; CHIEFFI, P. P.; BEnÍCIO, M. H. A. et al. - Estudo das condições de saúde das crianças do Município de São Paulo (Brasil), 1984/ 1985. VII. Parasitoses intestinais. Rev. Saúde públ. (S. Paulo), 22: 8-15, 1988.

8. RATHI, A. K.; BATRA, S.; CHANDRA, J. et al. - Ascariasis causing intestinal obstruction in a 45-day-old infant. Indian Pediat., 18: 751-752, 1981.

Recebido para publicação em 29/10/1996 Aceito para publicação em 25/09/1997 